\title{
Correction to: Organised crime and animals
}

\author{
Daan van Uhm ${ }^{1} \cdot$ Dina Siegel $^{1}$
}

(C) The Author(s) 2022

\section{Correction to: Trends in Organized Crime (2021) 24(4):419-424 https://doi.org/10.1007/s12117-021-09440-z}

The article Organised crime and animals, written by Daan van Uhm and Dina Siegel, was originally published Online First without Open Access. After publication in volume 24, issue 4, page 419-424 the author decided to opt for Open Choice and to make the article an Open Access publication. Therefore, the copyright of the article has been changed to (C) The Authors 2022 and the article is forthwith distributed under the terms of the Creative Commons Attribution 4.0 International License, which permits use, sharing, adaptation, distribution and reproduction in any medium or format, as long as you give appropriate credit to the original author(s) and the source, provide a link to the Creative Commons license, and indicate if changes were made. The images or other third party material in this article are included in the article's Creative Commons license, unless indicated otherwise in a credit line to the material. If material is not included in the article's Creative Commons license and your intended use is not permitted by statutory regulation or exceeds the permitted use, you will need to obtain permission directly from the copyright holder. To view a copy of this licence, visit http://creativecommons.org/licenses/by-nc/4.0.

The original article has been corrected.

Open Access This article is licensed under a Creative Commons Attribution 4.0 International License, which permits use, sharing, adaptation, distribution and reproduction in any medium or format, as long as you give appropriate credit to the original author(s) and the source, provide a link to the Creative Commons licence, and indicate if changes were made. The images or other third party material in this article are included in the article's Creative Commons licence, unless indicated otherwise in a credit line to the material. If material is not included in the article's Creative Commons licence and your intended

The original article can be found online at https://doi.org/10.1007/s12117-021-09440-z.

Daan van Uhm

d.p.vanuhm@uu.nl

Dina Siegel

Dina.s@uu.nl

1 Utrecht University, Newtonlaan 231, Utrecht 3584 BH, The Netherlands

Published online: 28 January 2022 
use is not permitted by statutory regulation or exceeds the permitted use, you will need to obtain permission directly from the copyright holder. To view a copy of this licence, visit http://creativecommons.org/ licenses/by/4.0/.

Publisher's note Springer Nature remains neutral with regard to jurisdictional claims in published maps and institutional affiliations. 